\title{
Analysis of knowledge loss trend in basic clinical sciences throughout medical education [Letter]
}

This article was published in the following Dove Press journal:

Advances in Medical Education and Practice

\section{Neelima Akter \\ Aysha Khalid}

Faculty of Medicine, St George's Hospital Medical School, London, UK
Correspondence: Neelima Akter

St George's University of London,

Cranmer Terrace, London SWI70RE, UK

Tel +44776325 7107

Email neelimakter@hotmail.co.uk

\section{Dear editor}

Knowledge retention is a challenge faced by many medical students in undergraduate teaching, and horizontal teaching of preclinical and clinical medicine is a popular curriculum that should be reflected upon. Based on this, we are greatly interested in the study conducted by Zaeemzadeh et al to encourage the vertical integration of basic sciences and clinical sectors. ${ }^{1}$ Most importantly the authors identified that knowledge loss occurred at all levels after basic sciences were taught, with knowledge loss decreasing as students advanced in their years at medical school. As medical students ourselves, we would like to offer our perspective on the feasibility of the authors' recommendations to promote vertical integration in medical schools.

The conclusion to teach clinical and basic sciences, particularly physiology, is a valuable one. As the author mentioned, it would be more effective for comprehending pathophysiology of disease. However, it may be impractical and difficult to organize, due to student's incomplete knowledge of all the domains in basic sciences and lack of facilities to prioritize junior medical students in practice over the senior students. This is an issue we have personally faced, with junior students receiving preference for space in clinics over seniors.

The study was of a good sample size of 356 volunteers; however, the survey conducted may have been an unrepresentative survey as it only included twenty questions and does not have the same level of preparation and question quantity as official exams. Moreover, previous exam results were used as cohort averages which is a not a fair comparison, as it is common for medical students to drop out of the course and this would disrupt the average. ${ }^{2}$ Likewise, cross-cohort comparison may not be fair as cohorts sit different exams with different questions and may have experienced different teaching due to curriculum changes. In addition, although the information on female students having better knowledge retention in comparison to the male students is an interesting one, the information is impractical to apply as the purpose of the study was done to promote vertical integration of basic sciences and clinical sectors, unless teaching was also to be adjusted according to gender.

The authors also concluded that physiology knowledge loss trend is inversely correlated to increments in retention time. In the discussion, the explanation for the better knowledge retention in s15 was owed to their greater experience and their higher rate of responsibility. The paper does not acknowledge that horizontal 
learning may be of use. Corroboration of knowledge through informal repetitive teaching in later years may serve as a form of learning in itself, as described by Vgotskys learning scaffold could be an alternative explanation for better knowledge retention in $\mathrm{s} 15 .^{3}$ Despite this, perhaps there is also knowledge loss through vertical learning.

Overall, we agree that learning in clinical years are the most memorable and useful for application onto real patients and vertical teaching may be useful in specific subjects. However, the benefits of curriculum solely based on vertical teaching are not well documented and the idea is fairly novel. Therefore, we propose that a trial be conducted on a small group of students for physiology with vertical teaching to compare against horizontal teaching before significant changes are made by the responsible authorities for the medical school.

\section{Disclosure}

The authors report no conflicts of interest in this communication.

\section{References}

1. Zaeemzadeh N, Taherpour S, Behzadian N, Mard SA. Evaluation of physiology knowledge loss in medical students of Ahvaz Jundishapur University of Medical Sciences. Adv Med Educ Pract. 2019;10:157-162. doi:10.2147/AMEP.S189029

2. Maher BM, Hynes H, Sweeney C, et al. Medical school attrition-beyond the statistics a ten year retrospective study. $B M C$ Med Educ. 2013;13:13. doi:10.1186/1472-6920-13-13

3. Vrenikina I. Scaffolding and learning: its role in nurturing new learners. In: Kell P, Vialle W, Konza D, Vogl G, editors. Learning and the Learner: Exploring Learning for New Times. Wollongong: University of Wollongong; 2008:161-175. Available from: https://ro.uow.edu.au/cgi/ viewcontent.cgi? article=1043\&context=edupapers. Accessed 17/04/19.

Dove Medical Press encourages responsible, free and frank academic debate. The content of the Advances in Medical Education and Practice 'letters to the editor' section does not necessarily represent the views of Dove Medical Press, its officers, agents, employees, related entities or the Advances in Medical Education and Practice editors. While all reasonable steps have been taken to confirm the content of each letter, Dove Medical Press accepts no liability in respect of the content of any letter, nor is it responsible for the content and accuracy of any letter to the editor.

\section{Publish your work in this journal}

Advances in Medical Education and Practice is an international, peerreviewed, open access journal that aims to present and publish research on Medical Education covering medical, dental, nursing and allied health care professional education. The journal covers undergraduate education, postgraduate training and continuing medical education including emerging trends and innovative models linking education, research, and health care services. The manuscript management system is completely online and includes a very quick and fair peer-review system. Visit http://www.dovepress.com/testimonials.php to read real quotes from published authors. 